\title{
IDŐJÁRÁSI VESZÉLYEK ÉS VESZÉLYJELZÉSEK MAGYARORSZÁGON
}

Weather risks and alerts in Hungary

\author{
LEELŐSSY ÁDÁM ${ }^{1}$ - VARGA-BALOGH ADRIENN² - HÉRINCS DÁVID³ \\ ELTE Eötvös Loránd Tudományegyetem Földrajz- és Földtudományi Intézet, Meteorológiai Tanszék \\ 1adam.leelossy@ttk.elte.hu, ${ }^{2}$ vargabaloghadrienn@gmail.com, ${ }^{3}$ herincs.david@gmail.com
}

\begin{abstract}
This study provides an overview on weather risks and available weather warning and prediction systems in Hungary. Most important weather risks include severe weather and thunderstorms with hail, flash floods and lightning damage; as well as winter precipitation, ice, frost, snow and freezing rain. The Hungarian Meteorological Service issues different weather warnings with 3-day and 3-hour time advantage to allow sufficient preparation for severe weather. Weather warnings, the basic understanding of meteorological background and responsible human response are all required to mitigate weather risks and reduce the avoidable damage.
\end{abstract}

Keywords: thunderstorm, weather risk, weather alert, severe weather

\section{BEVEZETÉS}

Modern világunk az időjárás sok veszélyétől megóv minket. A korszerü müszaki megoldások által nyújtott biztonságérzet és az egyre kevesebb szabadban töltött idő azonban sokszor óvatlansághoz vezet. Napjainkban is rendszeresek az időjárás által okozott tragikus balesetek. A sérülékeny műszaki berendezések elterjedése, az időjárásfüggő energiatermelés és az időjárási szélsőségek felerősödése pedig egyaránt az időjárás által okozott anyagi károk növekedése felé mutat. A jóléti társadalmakban az élet- és vagyonbiztonság fontos részét képezik a fejlett előrejelzési módszereken nyugvó időjárási veszélyjelzések és riasztások. Ezek azonban csak akkor érik el a céljukat, ha az érintett lakosság ismeri a hiteles információk forrásait és a károk megelőzéséhez és mérsékléséhez szükséges teendőket. A középszintű földrajz érettségi követelményei között ezért szerepel az időjárás okozta veszélyhelyzetek felismerése, a megelőzési és védekezési módok, illetve a másokért is felelős magatartás ismerete. A hiteles meteorológiai információkon alapuló jó döntések nemcsak a nemzetgazdaság, de egy-egy család biztonságának és vagyonának védelmét is szolgálják, és komolyra forduló helyzetekben életet is menthetnek. 


\section{AZ IDŐJÁRÁSI VESZÉLYFORRÁSOK}

Szűkebb értelemben időjárási veszélyforrásnak a veszélyes időjárási eseményeket tekintjük. Ezek hirtelen bekövetkező, rövid ideig tartó jelenségek, amelyek közvetlenül veszélyeztetik az emberi életet és a vagyont. A veszélyes időjárási események közé elsősorban a zivatarok és kísérőjelenségeik (széllökés, villámlás, felhőszakadás, jégeső és a tornádók) tartoznak. Azonban nem csak a zivataros időjárás jár veszélyekkel. Vannak télen jellemző veszélyes időjárási események: az ónos eső, a hófúvás és a fagy. Az élelmiszer- és energiaellátás, illetve a közlekedésbiztonság különösen sérülékeny az időjárási veszélyforrásokkal szemben. Sajátos időjárási veszélyekkel járnak a vízi és vízparti tevékenységek is. Tágabb értelemben időjárási veszélyforrásnak tekintjük a levegökörnyezeti kockázatokat is. Ezek olyan légköri körülmények, amelyek lassan alakulnak ki, tartósan fennállnak, és az emberi életben, illetve vagyonban mérhető káros hatásaik hosszú távon jelennek meg. Ilyen veszélyforrás elsősorban az erős UV-sugárzás, a hőség és a légszennyezettség.

A veszélyes időjárási jelenségek megelőzésére általában nincs mód, az okozott károk azonban csökkenthetők. Mára fejlett elörejelző rendszerek és széles körben elérhető tömegtájékoztatás biztosítja, hogy senkit ne érhessen meglepetésként az időjárás. Ennek, illetve főként kedvező éghajlatunknak köszönhetö, hogy Magyarországon viszonylag ritkák a heves időjárás által okozott halálesetek.

Az utóbbi évtizedek legsúlyosabb, heves időjárás által okozott tragédiája a 2006. augusztus 20-i tüzijátékra lecsapó vihar volt, ami öt ember életét követelte. 2007-ben Budapesten egy nyolcéves gyermek esett áldozatul egy porördögnek. Évente átlagosan 20-40 embert ér villámcsapás Magyarországon (BM 2013), ezek azonban csak ritkán halálos kimenetelüek. 2011-ben Gárdonyban, 2018-ban Gyenesdiáson történt halálos villámcsapás. 2015-ben az Óbudai-szigeten egy vihar által letört faág zuhant az alatta sátorozó férfira. 2020-ban Tótvázsonyban a saját kertjéből sodort el egy nőt a villámárvíz. A felsorolás nem lehet teljes, de megállapíthatjuk, hogy a veszélyes időjárási jelenségek hazánkban csak ritka esetekben követelnek közvetlenül emberéletet. Sajnos nem mondható el ugyanez a közlekedési balesetekről. 2015-ben 424 közúti balesetet okozott „a sebesség nem megfelelő alkalmazása az időjárási és látási viszonyokhoz" (KSH 2016. p. 18.). A veszélyes időjárási jelenségek tehát hazánkban elsősorban a közlekedési balesetekben játszott szerepükkel veszélyeztetik az emberéletet. Nagyon jelentősek azonban a heves időjárási eseményekkel járó vagyoni károk. A magyarországi biztosítótársaságokhoz a május-augusztus közötti szezonban évente körülbelül 100 ezer viharkárt jelentenek be lakástulajdonosok, amelyek együttes kárértéke évente 5-10 milliárd forint 
között volt a 2011-2020 időszakban (Magyar Biztosítók Szövetsége 2020). A mezőgazdasági biztosításokra 7 milliárd forint kárigényt ismertek el a 2020-as évben (AKI 2021).

$\mathrm{Az}$ időjárási veszélyforrásokra való felkészülésnek négy lényeges területe van: emberi, tárgyi, időbeli és pénzbeli. Az emberi felkészültség jelenti a felelős viselkedést, az időjárási körülményekhez alkalmazkodó óvatosságot, a hiteles elörejelzések és riasztások nyomon követését. A tárgyi felkészültség az otthonok és járművek biztonságához szükséges müszaki felszereléseket, utazás közben megfelelö ruházatot, élelmet, észszerü biztonsági tartalékokat foglalja magában. Az időbeli felkészültség jelenti a napi időbeosztás igazítását az időjárási körülményekhez; a lakás és a gépjármü biztonságossá tételéhez szükséges idő, valamint a megnövekedett utazási idő biztosítását, illetve az időjárás miatt átszervezett vagy lemondott programokat. A pénzbeli felkészültség jelenti a szükséges biztosítások és pénztartalékok meglétét, hogy az időjárás által okozott vagyoni károk vagy kisebb testi sérülések ne válhassanak egzisztenciális problémává.

Ebben a tanulmányban leírást adunk a legnagyobb veszélyt jelentő időjárási jelenségekről, a zivatarokhoz kapcsolódó heves időjárási jelenségekről, a téli időjárási veszélyekről és a hozzájuk kapcsolódó teendőkről, végül áttekintjük Magyarország időjárási veszélyjelző rendszerét.

\section{A ZIVATAROK ÉS KÍSÉRÖJELENSÉGEIK}

\section{Zivatar}

A zivatar összetett időjárási jelenség, amely alatt a villámlást és az azt kísérő többféle veszélyes jelenség (záporeső, felhőszakadás, jégeső, szélroham, tornádó) együttesét értjük (SÁNDOR V. - WANTUCH S. 2005). A zivatarok a legnagyobb függőleges kiterjedésü felhőkhöz, a zivatarfelhőkhöz (cumulonimbus) kapcsolódnak (1. ábra). Egy fejlett zivatarfelhő alapja 500-2000 $\mathrm{m}$, teteje 9-12 km magasságban található.

1. ábra. Zivatarfelhö Vas megyében 2009. május 25-én. A kép alján kivehetö a csapadéksáv, ettöl jobbra a csapadékmentes feláramlási zóna, a magasban pedig a szétnyúló üllő. (fotó: Hérincs D.) 
A felhő belsejében a feláramlás sebessége $30-50 \mathrm{~km} / \mathrm{h}$. A felszín közeléből beszívott meleg, nedves levegö több kilométert emelkedik, közben kicsapódik a nedvességtartalma. Az emelkedés során a cseppek hőmérséklete nyáron is a fagypont alá csökken, egy fejlett zivatarfelhő tetejénél körülbelül $-50^{\circ} \mathrm{C}$ hőmérséklet uralkodik (BARTHOLY J. et al. 2013). A kialakuló jégszemek ütközései elektromosan feltöltik a felhőt, légelektromos jelenségeket okozva. A feláramló levegő a troposzféra tetejét elérve oldalirányba szétterül, és kialakítja a zivatarfelhők jellegzetes üllőjét. A feláramlásból kikerülő cseppek és jégszemek a feláramlási torony mellett lefelé zuhannak, és a felszínen intenzív csapadékhullást okoznak. A zivatarokhoz többféle veszélyes kísérőjelenség kapcsolódik (2. ábra).

\section{Villámlás}

A felszínt elérő (ún. lecsapó) villámok között megkülönböztetünk pozitív és negatív villámokat attól függően, hogy a zivatarfelhőnek milyen töltésű részéről indulnak. A negatív villámok a leggyakoribb, csúcsos, magas tárgyakba csapó villámok, amelyek általában a felhő alsó részéről indulnak. A pozitív villámok nem részesítik előnyben a csúcsos tárgyakat, és általában a felhő magasabb részeiből indulnak. A zivatarfelhő

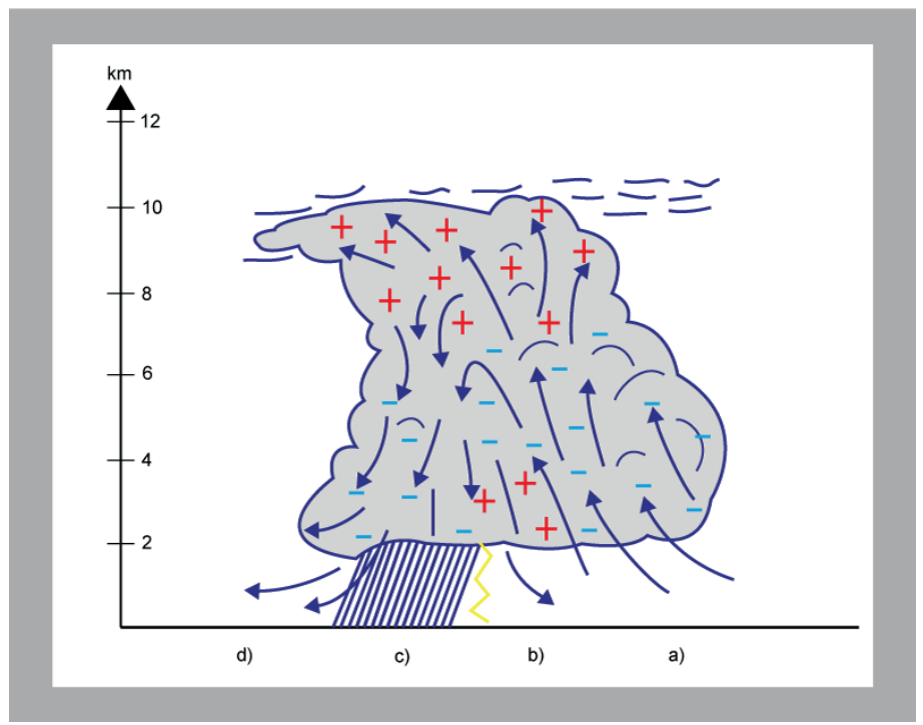

2. ábra. Zivatarfelhö szerkezete a fel-és leáramlási viszonyokkal és az elektromos töltések eloszlásával. Kapcsolódó veszélyforrások a felhö egyes részein: a) feláramlási torony: negatív töltésü villám, tornádók lehetséges helye; b) pozitív töltésü villám, jégeső; c) csapadéksáv: felhöszakadás, széllökés, negatív töltésü villám; d) kifutószél, szépidö-villám (forrás: Hérincs D.) 
tetejétől indulva a csapadéksávtól nagyobb távolságban is lecsaphatnak. Ezeket nevezzük szépidö-villámoknak (3. ábra). Bár a pozitív villámok csak az összes lecsapó villám 5-10\%-át teszik ki, erősségük és sokszor meglepetésszerü érkezésük miatt ezek felelősek a villámkárok és az embereket érő balesetek nagy részéért. A villámlást kísérő mennydörgés a zivatarfelhő 20-30 kilométeres környezetében hallható, körülbelül ugyanezt a területet érhetik el a szépidő-villámok is. Tehát a hallható dörgés jól jelzi a villámcsapás veszélyét. A villámok fénye azonban jóval messzebbről, nappal 50-100, éjszaka sok száz kilométerről is látható.

\section{Széllökés}

A zivatarfelhő leáramlási részén hulló csapadék esése közben olvad, illetve párolog, ami lehűti a körülötte lévő levegőt. A hideg levegő nagyobb sürüsége okán lefelé áramlik, így a csapadékkal együtt egy hideg légzuhatag is a felszín felé zúdul. A felszínt elérve a víz és a jég a talajon marad, a velük együtt leáramló levegő azonban oldalra kitér, és ún. kifutószelet okoz. A kifutószél a csapadéksávtól kifelé fújó, a környezeténél hidegebb, erős, lökéses szél, ami a felhőtől 10-30 km távolságig érezhető, sebessége pedig 50-150 $\mathrm{km} / \mathrm{h}$ közötti. Ereje, lökésessége és sokszor meglepetésszerủ érkezése miatt a kifutószél okozza a viharkárok legnagyobb részét.

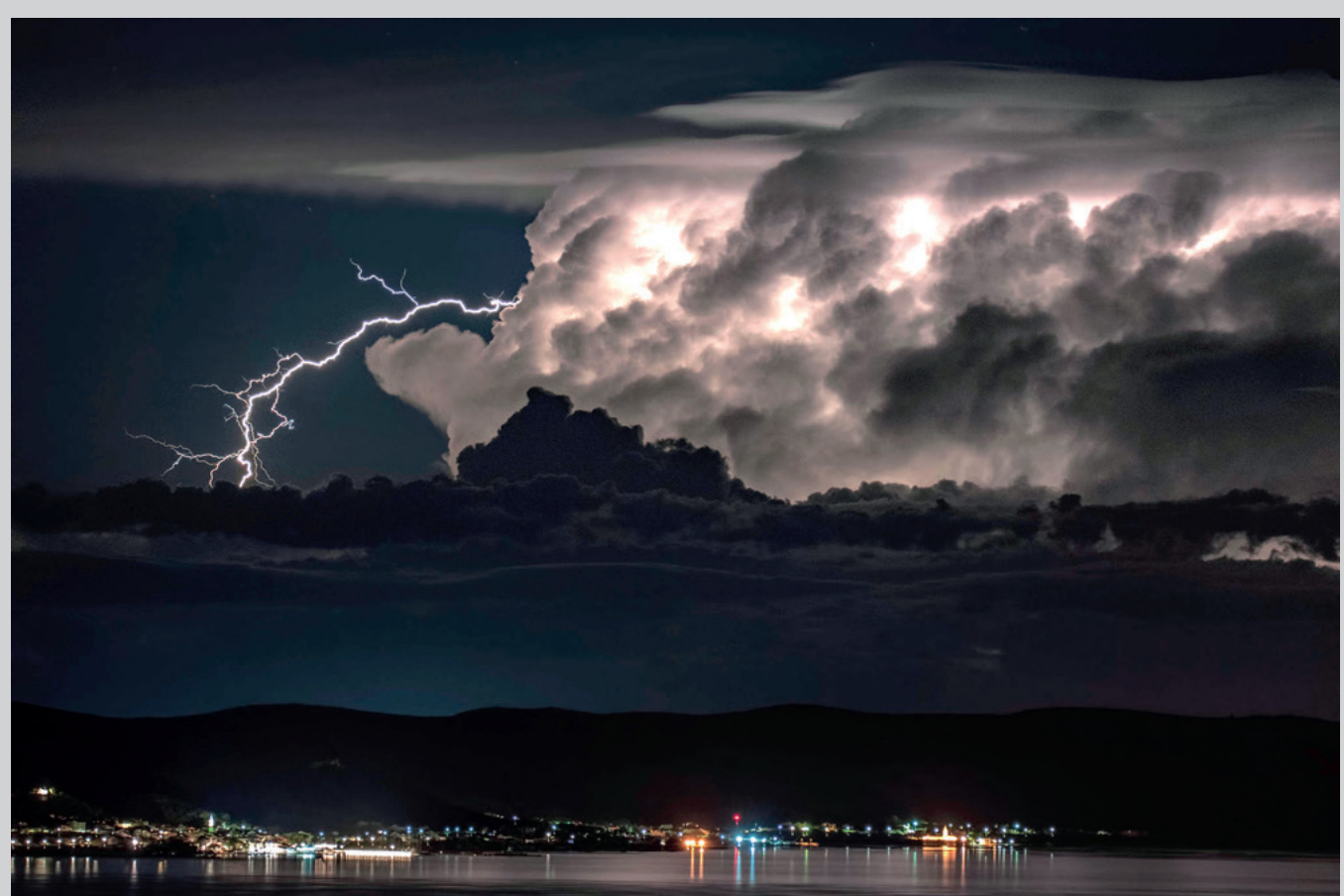




\section{Felhőszakadás és jégeső}

A széllökések mellett a zivatarokkal járó intenzív csapadék a viharkárok másik fő oka. Egy zivatarfelhőből egy adott pontban lezúduló csapadékösszeg általában 10-20 mm (BARTHOLY J. et al. 2013). Ha azonban a zivatarfelhők lassan mozognak, vagy egymás után több zivatarcella is áthalad egy adott pont felett, akkor ennek a mennyiségnek a sokszorosa is összegyülhet. A Magyarországon mért legnagyobb napi csapadékösszeg 260 mm (Dad, 1953. június 9.). Elsősorban hegy- és dombvidéken jellemző, hogy a patakok, vízmosások és csatornák kilépnek a medrükből, és villámárvizet okoznak (Czigány Sz. - Pirkhoffer E. 2018) (4. ábra). Az értékeiket menteni igyekvő, vagy hidak alatt meghúzódó emberek gyakran alábecsülik a víz erejét, amely meredek hegyoldalakon $50-100 \mathrm{~km} / \mathrm{h}$ sebességre gyorsul, és percek alatt elérheti a biztonságosnak gondolt menedék szintjét. A villámárvizek erősségét fokozza a szűk, eltorlaszolt meder, illetve a nedves, sáros, esetleg fagyos talaj. A településeken gyakran okoz károkat a csapadékelvezető rendszer kapacitásait meghaladó mennyiségü, hirtelen lezúduló csapadék.

Jégesővel a felhő feláramlási és leáramlási csatornájának határán, a csapadéksáv szélén találkozhatunk. Itt töltenek a legtöbb időt a jégszemek a felhőben, többször is oda-vissza haladva a le- és feláramlási csatornák között. A felszínt elérő jégszemek mérete a terményt veszélyeztető borsó mérettől a komoly épületkárokat is okozó teniszlabda méretig terjed.

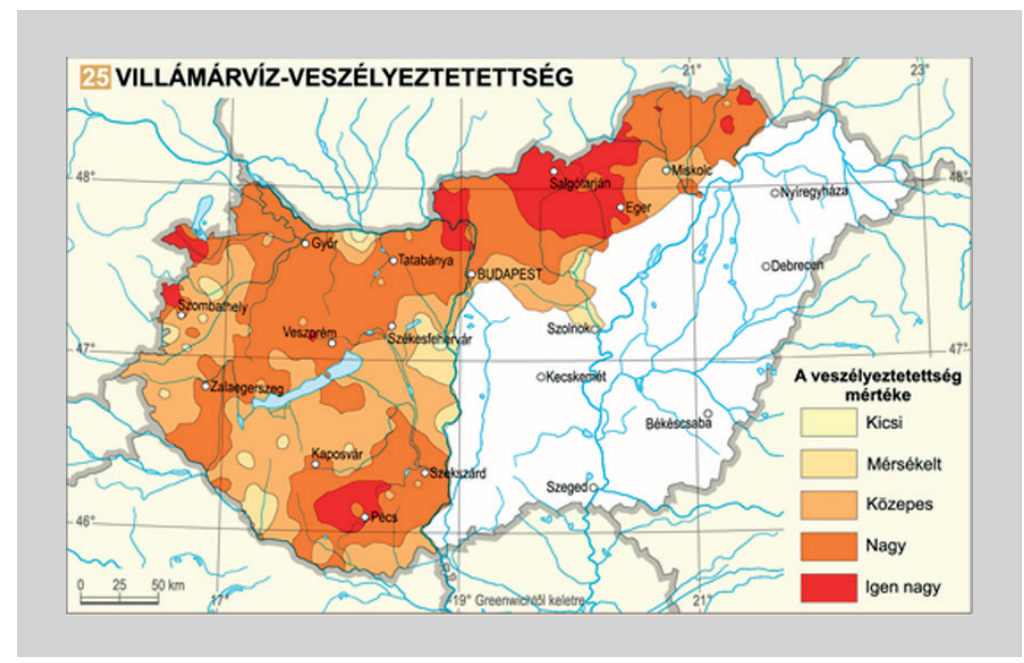

4. ábra. Villámárvíz-veszélyeztetettség Magyarországon (forrás: Czigány Sz. - Pirkhoffer E. 2018) 


\section{Teendők zivataros időjárás esetén}

A legtöbb kárt a széllökések által letört faágak és törmelék, illetve a villámárvizek okozzák. Zivataros időben fokozott veszélyben vagyunk

- a szél miatt: fák alatt, épületek falai mellett, állványok, színpadok, nagy sátrak, légvárak, kivetítők közelében;

- a felhőszakadás miatt: aluljáróban, vízmosásokban, kisebb vízfolyások partján;

- a villámlás miatt: vízen és vízparton, hegygerincen, gáton, dombtetőn, háztetőkön, szántón, sportpályán.

Természetesen a legjobb a zivatar elől biztos menedéket nyújtó épületbe menekülni. Előzzük meg az ablakok becsapódását, a párkányon, korláton lévő tárgyak kirepülését - ezzel nemcsak saját vagyonunkat, de a házunk közelében tartózkodók épségét is védjük. Autóban is biztonságban vagyunk, ha nem fa alatt vagy aluljáróban parkolunk. Gyakori hiba, hogy gépjármüvüket a jégesőtől féltő autósok fák vagy hidak alatt keresnek menedéket. Azonban az autóra dőlő fák sokkal nagyobb, akár halálos veszélyt jelentenek, mint a jégszemek. A víz pedig az alacsonyan fekvő aluljárókat önti el először, ahol az autók és utasaik könnyen csapdába kerülhetnek. Ha a szabadban kell átvészelnünk a zivatart, akkor keressünk olyan helyet, ahol lehetőleg nem esik ránk semmi (a szél miatt), de mi sem emelkedünk ki a környezetünkből (a villámlás miatt), és nem is a környék legmélyebb pontján állunk (a felhőszakadás miatt). Kisebb erdei tisztásokon, városi tereken, gátak védett oldali tövében meghúzhatjuk magunkat. Zivatar idején a fa alatt vagy a patakparton felvert sátrat el kell hagyni; szántóról, vízről, sportpályáról le kell vonulni. A villámlás még megfelelő villámvédelemmel ellátott házban is okozhat elektromos zavarokat, ezért érdemes az érzékeny készülékeket kihúzni az elektromos csatlakozóból, és felkészülni egy esetleges áramszünetre.

A modern technikának és tömegtájékoztatásnak köszönhetően a zivatar érkezése már kevésbé érhet minket meglepetésként. A várható zivatarokról az időjárási veszélyjelzés, a már kialakult zivatarok pontos helyéröl és útvonaláról a radarkép tájékoztat (HADVÁRI M. et al. 2018, Mészáros R. 2013). Fontos azonban figyelembe venni, hogy a zivatarfelhő vízszintes mérete rendkívül kicsi: az egész zivatarfelhő mindössze 5-30 km kiterjedésü, ezen belül a csapadéksáv 0,5-10 km széles (ez jól megfigyelhető az 5. ábrán). Sokszor csak egy-egy településrészt érint egy zivatar, vagy éppen áthalad két település között. A kiadott veszélyjelzés, de még a hallható dörgés sem biztosíték arra, hogy a vihar elér minket; ez sokszor néhány utcán, egy-két kilométeren múlik. Mivel azonban a zivatarfelhők pontos útvonala kiszámíthatatlan, sok kísérőjelenségük (kifutószél, villámlás, villámárvíz) pedig a felhőtől távolabb is képes károkat okozni, ezért a felkészülés mindig a zivatar által veszélyeztetett egész területen indokolt - nem csak ott, ahol a vihar végül valóban lecsap. 

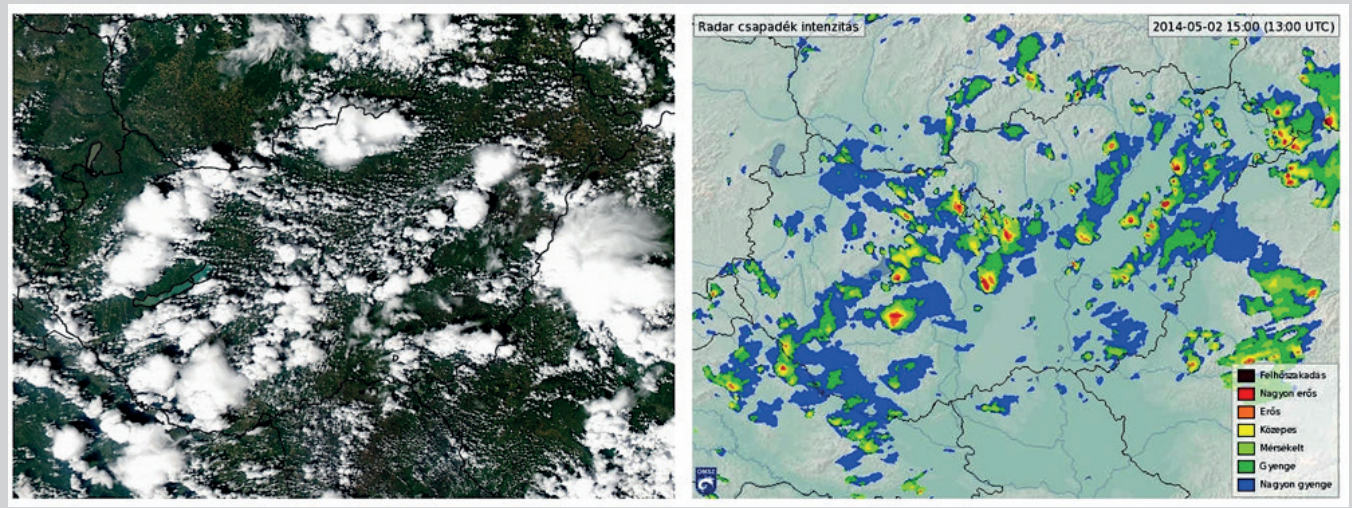

5. ábra. Zivatarok Magyarország felett 2014. május 2-án müholdképen (balra) és radarképen (jobbra). A két kép 1 óra 42 perc időkülönbséggel készült. (forrás: müholdkép: Kern A., http://nimbus.elte.hu/kutatas/ sat/, radarkép: Országos Meteorológiai Szolgálat, https://www.met.hu/idojaras/aktualis_idojaras/radar/)

\section{Forgószelek}

A zivatarok félelmetes, ritka kísérőjelensége a tornádó (6. ábra). A felhő feláramlási csatornája alól lenyúló tölcsérben a szélsebesség a 300-400 km/h-t is elérheti (BARTHOLY J. et al. 2013). A tölcsér szélessége 1-2000 m, élettartama pár másodperctől 30 percig terjed. Kis méretük és rövid élettartamuk miatt a tornádók nagy része észrevétlen marad, vagy csak

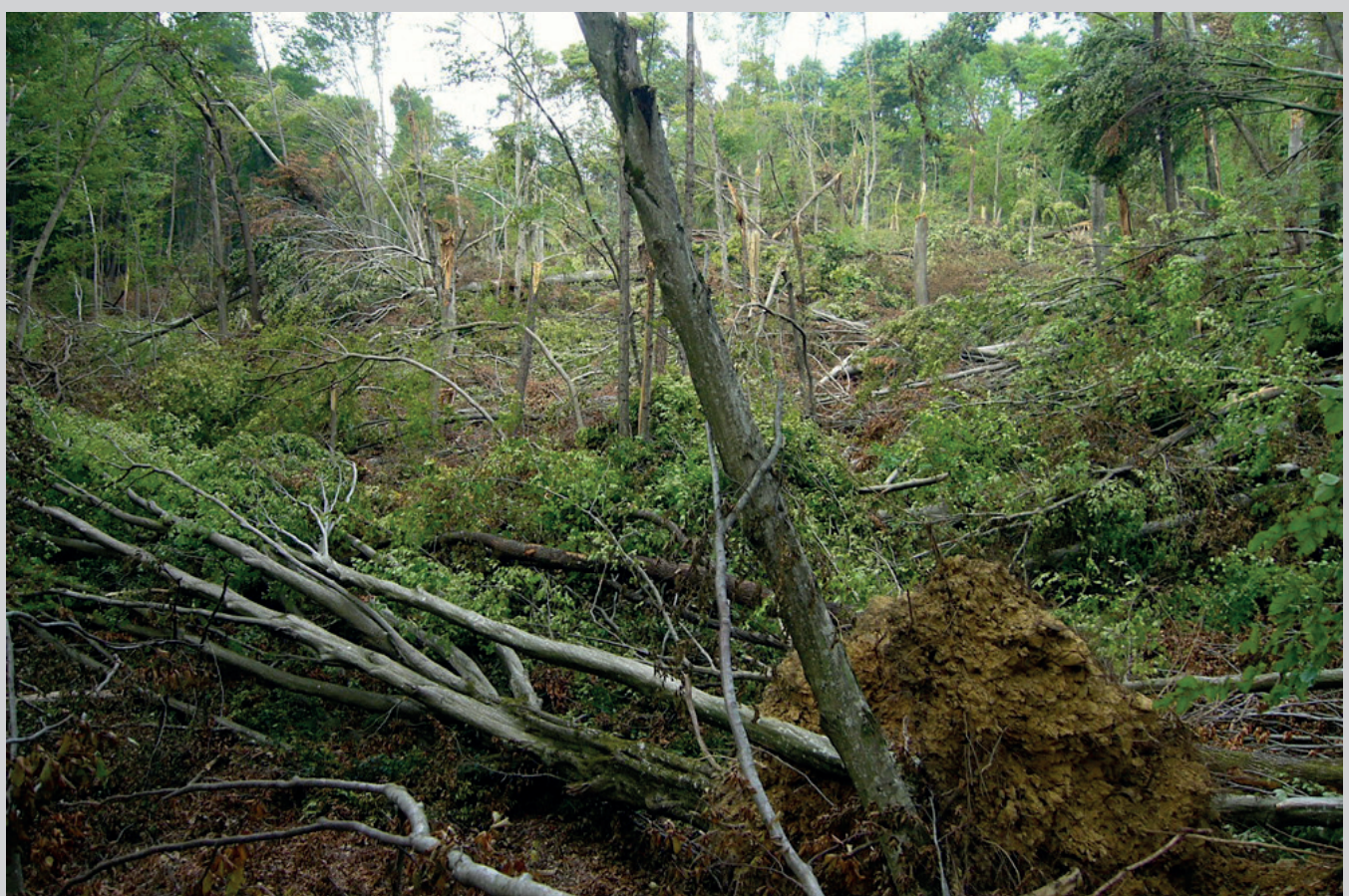


károkozása alapján azonosítható (6. ábra). Az Időkép (idokep.hu) észlelői 2020-ban kettő, 2021-ben hat tornádót jelentettek Magyarországon. Tényleges számuk ennek öt-tízszeresére becsülhető. Hazánk eddigi legnagyobb feljegyzett tornádója 1924-ben öt halálos áldozattal járt, elpusztította az akkori Bia, Torbágy és Páty települések egy részét, és jelentős erdőkárokat okozott a Pilisben (АрAтóczky I. 2004). Hogy ma egy lakott területet elérő tornádó milyen következményekkel járhat, arra szomorú példát láttunk 2021. június 24-én Csehországban, ahol egy 350-400 km/h szélerősségű tornádó $700 \mathrm{~m}$ szélességben és 26 km hosszban pusztított, az 1600 fős Hrušky falu központján áthaladva hat halálos áldozat és több száz sérült mellett körülbelül 200 milliárd forint anyagi kárt hagyott maga után.

A tornádók mindig zivatarokban alakulnak ki, de van szép időben megjelenő rokonuk is, a porördög (7. ábra). Ez a napos időben, a forró felszín felett kialakuló portölcsér sokkal szelídebb és gyakoribb is a tornádóknál. Átmérője legfeljebb 20 m, benne a szélsebesség is alacsonyabb, csupán $50-100 \mathrm{~km} / \mathrm{h}$. A tornádókhoz hasonlóan többségük észrevétlen marad, és legfeljebb a növényzetben okoz károkat. A napos, eseménytelen időjárásban meglepetésszerüen felbukkanó forgószél azonban veszélyes lehet, ha szabadtéri rendezvényeket, színpadokat, légvárakat vagy siklóernyősöket érint.

\section{A TÉLI IDŐJÁRÁSI VESZÉLYFORRÁSOK}

A téli időjárás különlegessége a sokféle csapadéktípus megjelenése. A felszínre érő cseppek halmazállapotát a felettük lévő levegőoszlop hőmérsékleti eloszlása határozza meg

7. ábra. Tornádó és porördög a Fejér megyei Perkátán 2017. május 23-án, illetve 2019. április 10-én (fotó: Papp P. - Pappné Szebellédi T., Viharvadászok Egyesülete)

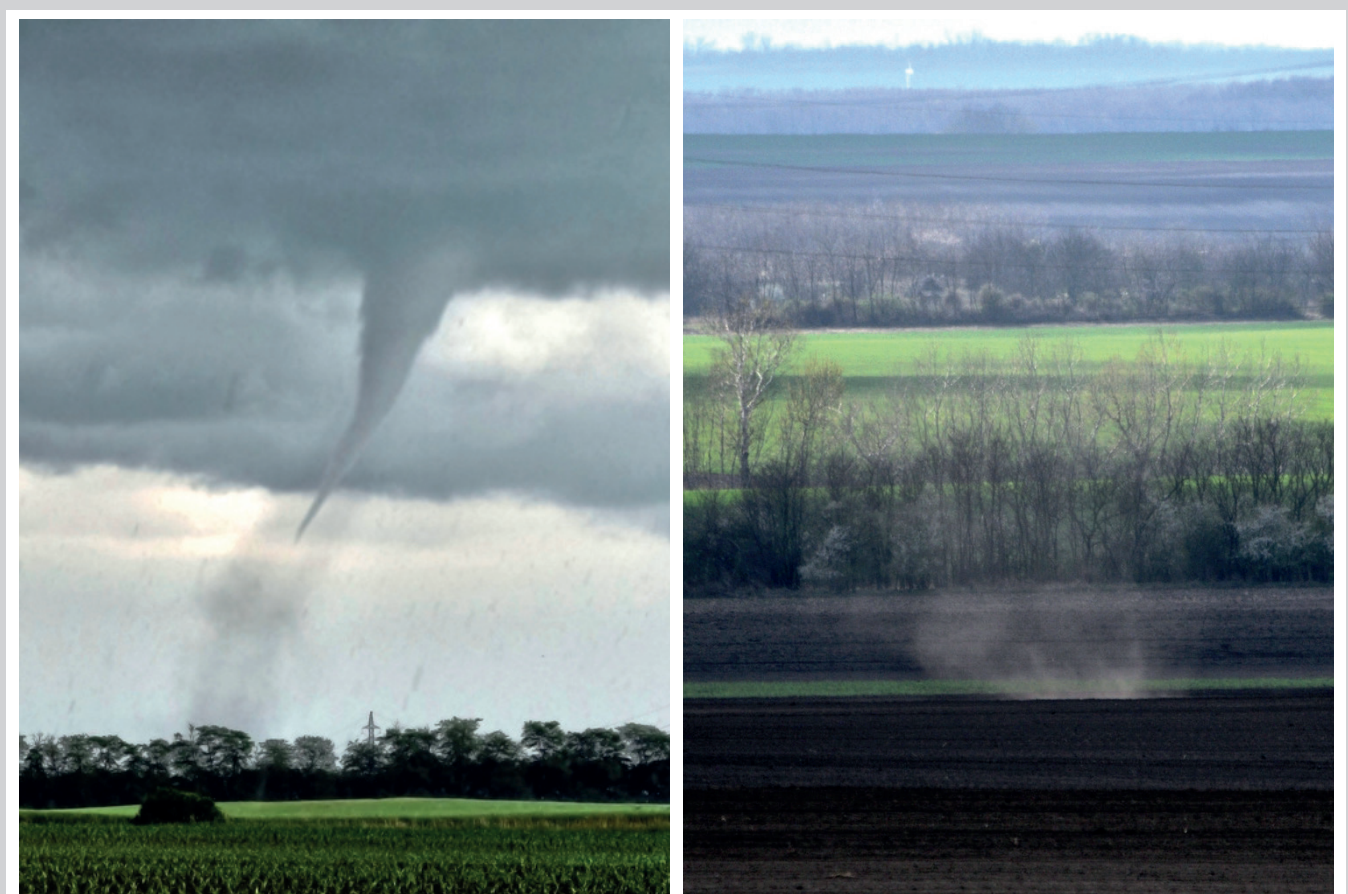


(BARTholy J. et al. 2013). A felhő szintjén télen általában szilárd halmazállapot jellemző. Ha a légoszlop végig negatív hőmérsékletű, akkor havazást tapasztalunk. Ha az alsóbb rétegekben pozitív hőmérsékletet mérünk, akkor a hulló jégkristályok részben vagy teljesen megolvadnak, és a felszínen havas esőt vagy esőt láthatunk. Télen gyakran előfordul azonban, hogy a meleg levegö alatt, a felszín közelében megreked egy néhány száz méter vastagságú fagyos légréteg. A már elolvadt hópelyhek ilyenkor ismét lehủlnek. Ha teljesen visszafagynak, akkor fehéres színű jégszemek, fagyott eső hullik. Ha a fagypont alá visszahűlt cseppek folyékonyak maradnak, és fagypont alatti felszínelemeket, tereptárgyakat érnek, akkor ónos eső alakul ki (8. ábra). A téli csapadékfajták közül az ónos eső a legveszélyesebb: a túlhűlt vízcseppek a felszínt elérve azonnal megfagynak, és vékony jégréteggel borítják be azt.

Télen tehát sokszor az olvadás magasságában bekövetkező csekély változások, illetve 1-2 ${ }^{\circ} \mathrm{C}$-os hőmérsékletkülönbségek döntenek arról, hogy melyik csapadékfajta alakul ki. A korlátolt előrejelezhetőség mellett ez azt is jelenti, hogy sokszor percek alatt, vagy utazás közben pár száz méter megtétele alatt változnak a csapadékfajták által meghatározott látási és síkossági viszonyok. Különösen hegy- és dombvidéken közlekedve jellemző, hogy a hőmérséklet magasság szerinti változásai miatt ugrásszerü változások következnek be a látási és útviszonyokban.

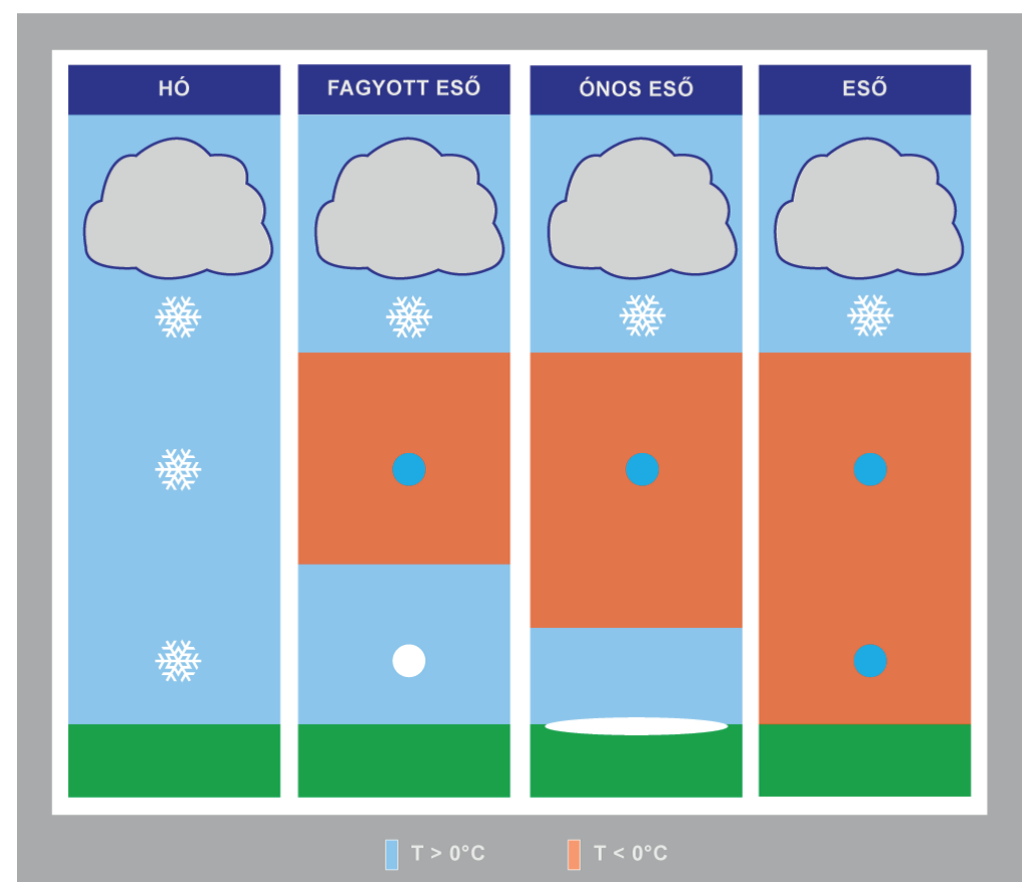

8. ábra. Téli csapadéktípusok különbözö függöleges hömérsékleti eloszlás mellett (forrás: COMET ${ }^{\otimes}$ University Corporation for Atmospheric Research) 
A bevezetőben bemutattuk, hogy Magyarországon az időjárással közvetlenül összefüggésbe hozható halálesetek nagy többsége a közlekedési balesetekhez kötődik. A közlekedőknek leginkább a téli időszakban kell figyelemmel kísérniük az időjárást, gyalogosan és autóval egyaránt. A balesetek elkerüléséhez szükséges óvatosság mellett elengedhetetlen az elakadásra, illetve a menetidő megnövekedésére való felkészülés is. Már késő ősztől jellemző a hajnali órákban képződő köd és talajmenti fagy. Utóbbi kis területen csúszós útszakaszt eredményez, különösen a hidakon és a felüljárókon. Alattomos téli veszélyforrás a felszínt borító átlátszó, vékony jégréteg: a tiszta jég, köznapi nevén tükörjég (9. ábra). Általában ónos eső hozza létre, de létrejöhet a felszínen megfagyó vízből is. Napsütötte felszínen gyorsan elolvad, de árnyékos foltokban, kisebb mélyedések alján váratlanul meglepheti a közlekedőt. $3{ }^{\circ} \mathrm{C}$-os hőmérséklet alatt mindig készen kell állni a tapadási viszonyok hirtelen romlására. A közlekedés teljes elakadását okozhatja a hófúvás, amely akkor keletkezik, ha a hőmérséklet tartósan fagypont alatt marad, a lehullott hó nem tud összetapadni, és az erős szél az útra fújja azt.

Sokszor alábecsült, de minden télen 100-300 honfitársunk életét követelö légköri veszélyforrás a fagy. A hideg hamar kimeríti az emberi szervezetet, és olyan köznapi balesetek is életveszélyessé válhatnak, mint egy elcsúszás vagy az ittasság. A fagyhalál elsősorban szociális kérdés. Nagy hidegben fokozott szükség van a kölcsönös odafigyelésre és segítségnyújtásra. Ne tágítsunk, ha valaki a szabadban tervezi tölteni az éjszakát, vagy órákkal később érkező autóbuszra vár! Ittas embert ne engedjünk egyedül útnak indulni, magányos idősekkel gyakran telefonáljunk! Nagy hidegben alapvető emberi

9. ábra. Téli útviszonyok: hó az útpadkán, jég és tükörjég az úton (fotó: Hérincs D.)

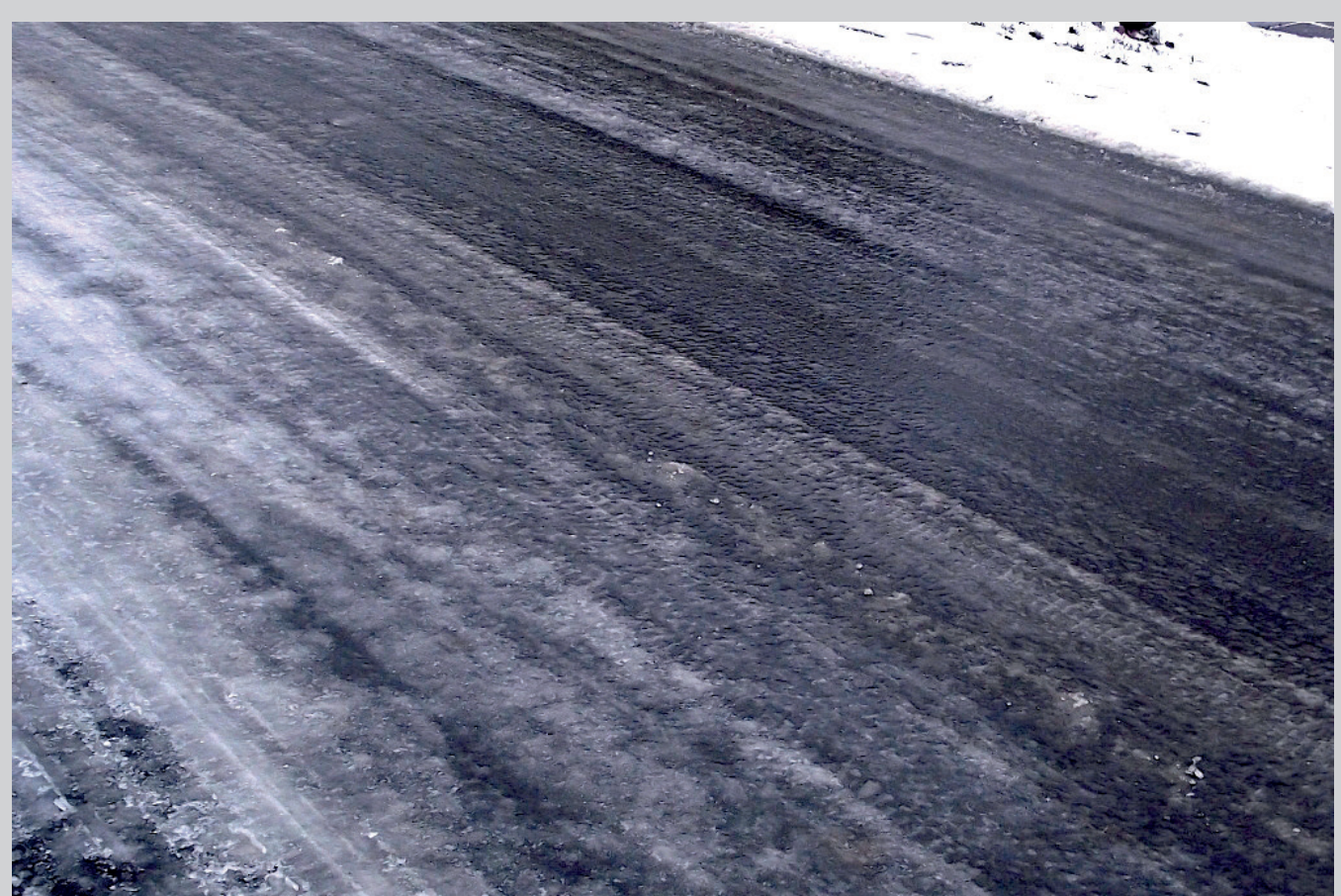


kötelesség, hogy minden földön fekvő ember, út szélén álló gépkocsi mellett álljunk meg! A szociális intézmények és segélyszervezetek ilyenkor általában rendkívüli ügyeletet működtetnek, érdemes ezek telefonszámát előre elmenteni (Menhely Alapítvány 2017).

\section{MAGYARORSZÁG IDŐJÁRÁSI VESZÉLYJELZÖ RENDSZERE}

Magyarországon a különbözö időjárási veszélyforrásokra több intézmény többféle veszélyjelzés formájában hívja fel a lakosság figyelmét. Ezeket az 1. táblázatban foglaljuk össze. A veszélyjelzések fokozatai az elsőfokú (legenyhébb) figyelmeztetéstől másod-, illetve harmadfokig fokozódó kockázatot jeleznek.

\section{Figyelmeztető elörejelzés}

1-3 napos időtávon a veszélyes időjárási jelenségekre való felkészülés legfontosabb információforrása az Országos Meteorológiai Szolgálat figyelmeztető előrejelzése. Adott

\begin{tabular}{|c|c|c|c|c|c|c|c|}
\hline & Veszélyforrás & $\begin{array}{l}\text { Fokozatok } \\
\text { száma }\end{array}$ & $\begin{array}{l}\text { Területi } \\
\text { hatály }\end{array}$ & $\begin{array}{l}\text { Időbeli } \\
\text { hatály }\end{array}$ & $\begin{array}{l}\text { Idő- } \\
\text { elöny }\end{array}$ & $\begin{array}{l}\text { Elrendelö } \\
\text { intézmény }\end{array}$ & Forrás \\
\hline \multirow[t]{2}{*}{ Riasztás } & $\begin{array}{l}\text { Zivatar, széllökés, } \\
\text { ónos eső, hófúvás }\end{array}$ & 3 & \multirow[t]{2}{*}{ járás } & \multirow[t]{2}{*}{$\begin{array}{l}\text { visszavo- } \\
\text { násig }\end{array}$} & \multirow[t]{2}{*}{3 óra } & \multirow[t]{2}{*}{ OMSZ } & \multirow{5}{*}{$\begin{array}{l}\text { http://www.met. } \\
\text { hu/idojaras/ } \\
\text { veszelyjelzes/ }\end{array}$} \\
\hline & Felhőszakadás & 2 & & & & & \\
\hline \multirow[t]{3}{*}{$\begin{array}{l}\text { Figyelmeztető } \\
\text { előrejelzés }\end{array}$} & $\begin{array}{l}\text { Zivatar, széllökés, } \\
\text { ónos eső, hófú- } \\
\text { vás, eső, havazás, } \\
\text { hideg, hőség }\end{array}$ & 3 & \multirow[t]{3}{*}{ megye } & \multirow[t]{3}{*}{$\begin{array}{l}\text { megadott } \\
\text { napra }\end{array}$} & \multirow[t]{3}{*}{3 nap } & \multirow[t]{3}{*}{ OMSZ } & \\
\hline & Felhöszakadás & 2 & & & & & \\
\hline & Köd & 1 & & & & & \\
\hline Viharjelzés & Szél/hullám & 2 & tó & $\begin{array}{l}\text { visszavo- } \\
\text { násig }\end{array}$ & 1 óra & OMSZ & $\begin{array}{l}\text { https://www. } \\
\text { met.hu/idoja- } \\
\text { ras/tavaink/ }\end{array}$ \\
\hline $\begin{array}{c}\text { UV- } \\
\text { figyelmeztetés }\end{array}$ & UV-sugárzás & 2 & régió & $\begin{array}{l}\text { megadott } \\
\text { napra }\end{array}$ & 1 nap & OMSZ & $\begin{array}{l}\text { https://www. } \\
\text { met.hu/idoja- } \\
\text { ras/humanme- } \\
\text { teorologia/uv-b/ } \\
\text { figyelmeztetes/ }\end{array}$ \\
\hline Hőségriadó & hőség & 3 & ország & $\begin{array}{l}\text { megadott } \\
\text { napokra }\end{array}$ & 1 nap & $\begin{array}{l}\text { Tisztiföor- } \\
\text { vos }\end{array}$ & $\begin{array}{l}\text { https://www. } \\
\text { nnk.gov.hu/ } \\
\text { index.php/ } \\
\text { nnk-kozleme- } \\
\text { nyek }\end{array}$ \\
\hline Szmogriadó & $\begin{array}{r}\text { légszennyezett- } \\
\text { ség }\end{array}$ & 2 & $\begin{array}{l}\text { telepü- } \\
\text { lés }\end{array}$ & $\begin{array}{l}\text { megadott } \\
\text { napokra }\end{array}$ & utólag & $\begin{array}{l}\text { önkor- } \\
\text { mányzat }\end{array}$ & \\
\hline
\end{tabular}

1. táblázat. Időjárási veszélyjelzések Magyarországon (szerk.: Leelőssy Á.) 
napra és megyére vonatkozóan hívja fel a figyelmet a károkozó széllökés, zivatar, ónos eső, hófúvás, nagy mennyiségű havazás, extrém hideg, illetve hőség bekövetkezésének esélyére. Az elörejelzés kategóriája (sárga, narancssárga, piros) a veszélyforrás várható erősségét jelzi.

\section{Teendök}

Utazás, szabadtéri program előtti 1-3 napban látogassuk meg a figyelmeztető előrejelzés weboldalát! Kiadott figyelmeztetés esetén kövessük alapos figyelemmel az időjárás-előrejelzést, készüljünk fel a program esetleges átszervezésére! A program napján rendszeresen figyeljük a riasztást és a radarképet! Vigyünk magunkkal tartalék élelmet, meleg ruhát arra az esetre, ha az időjárás átírja a terveinket! Legyen kész tervünk arra az esetre, ha a veszélyes időjárási esemény bekövetkezik (mennyi idő alatt tudunk biztos helyre húzódni, hogyan jutunk haza?)!

\section{Riasztás}

Az időjárási riasztások a veszélyes időjárási képződmények közeledését jelzik, általában azonnali teendőt igényelnek. A riasztást a zivatar, a károkozó széllökés, az ónos eső, a hófúvás vagy a felhőszakadás bekövetkezése előtt 0-3 órával adja ki az Országos Meteorológiai Szolgálat adott járásra vonatkozóan. Zivatar és felhőszakadás esetén a riasztás a radarképpel együtt nyújt részletes, aktuális információt a vihar helyzetéről és mozgásáról (10. ábra).
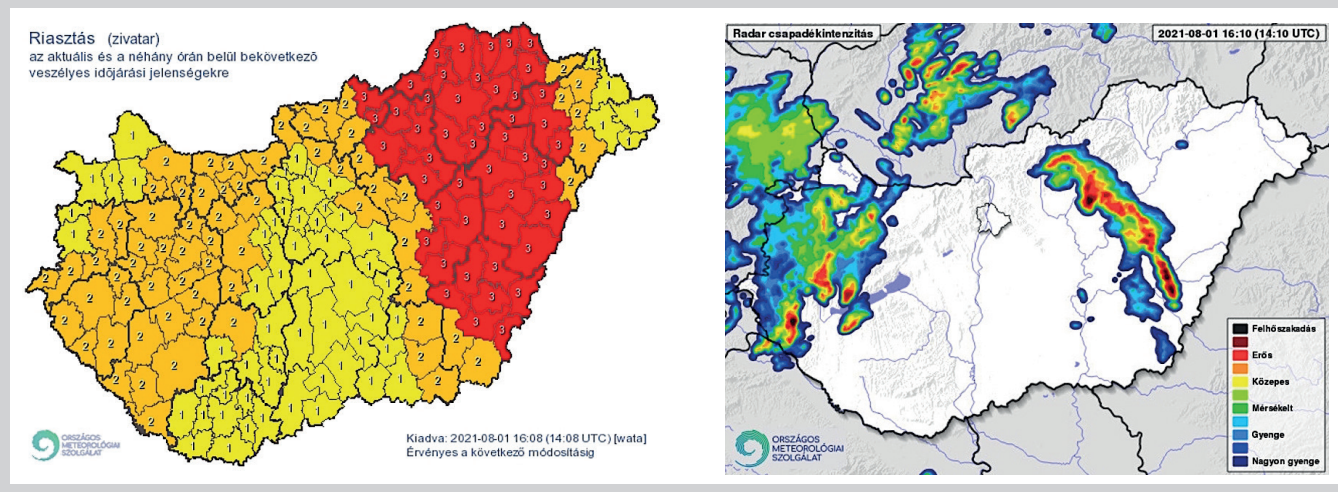

10. ábra. Példa a következő 3 órában várható zivatarok miatt kiadott riasztásra (balra) és az aktuális radarkép (jobbra) 2021. augusztus 1. 16:10 órakor (forrás: Országos Meteorológiai Szolgálat) 


\section{Teendök}

$\mathrm{Az}$ adott napra érvényben lévő figyelmeztető elörejelzés esetén a riasztást szabadtéri program, illetve utazás során rendszeresen követni kell. Kiadott riasztás esetén készüljünk fel a szabadtéri tevékenység megszakítására! Készen kell állni arra, hogy az időjárás akár percek alatt kedvezőtlen fordulatot vesz. Mérjük fel, hogy mit, hová, mennyi idő alatt tudunk biztonságba helyezni! Kerüljünk távolabb a tömegtől, hagyjunk magunknak teret és lehetőséget a menekülésre!

\section{Viharjelzés}

A viharjelzéssel tavi, vízparti tartózkodás során találkozhatunk, a Balatonon, a Velenceitavon és a Tisza-tavon müködik a nyári félévben. A viharjelzés kiadásáról leglátványosabban a part mentén villogó lámpák tájékoztatnak, de az interneten és a TaVihar okostelefonos alkalmazásban is nyomon követhető.

\section{Teendök}

Elsőfokú viharjelzés (1 másodpercnél ritkábban villogó lámpa) esetén úszva és csónakkal is maradjunk a part közelében, sekély vízben! Álljunk készen arra, hogy szükség esetén perceken belül a parton lehessünk. Mérjük fel a szélirányt! A part felől fújó szél esetén veszélyben vagyunk - haladéktalanul tartsunk a part felé, mert nem biztos, hogy erre később is képesek leszünk! Semmiképpen ne ússzunk a mély vízre kisodort gumimatracok, játékok után! Másodfokú viharjelzés (1 másodpercnél sűrűbben villogó lámpa) esetén a legrövidebb úton menjünk ki a partra!

\section{UV-figyelmeztetés}

Az UV-sugárzásra vonatkozó figyelmeztetést egy napra előre adja ki az Országos Meteorológiai Szolgálat. Figyeljünk az UV-sugárzásra, ha huzamosabb időt készülünk a szabadban tölteni: például mezőgazdasági munkát végzünk, sportolunk, strandolunk vagy síelünk!

\section{Teendők}

Sapkával, ruhával, napszemüveggel, napvédő krémmel védekezhetünk az UV-sugárzás ellen. Teendőinket igyekezzünk úgy szervezni, hogy a déli órákat árnyékban tölthessük! 


\section{Hőségriadó}

Hőségre vonatkozóan kétféle veszélyjelzés is létezik. A Tisztifőorvos rendeli el a hőségriadót, az Országos Meteorológiai Szolgálat pedig hőségre vonatkozó figyelmeztető elörejelzést ad ki. A két jelzés nem teljesen azonos kritériumok alapján készül, így előfordul, hogy egyszerre van érvényben harmadfokú hőségriadó és másodfokú hőségre vonatkozó figyelmeztető előrejelzés. A hőségriadó a munkaadók és intézmények számára kötelező érvényű szabályokkal jár, míg a figyelmeztető előrejelzés a lakosság tájékoztatására szolgál.

\section{Teendök}

Rövidebb utakra is vigyünk magunkkal vizet és sapkát! A sportolást, fizikai munkát, utazást halasszuk hűvösebb napokra, vagy végezzük el kora reggel! Kerüljük el lakásunk felhevülését árnyékolással, éjszakai szellőztetéssel, esti vagy kora reggeli sütés-főzéssel! Teendőinket igyekezzünk úgy szervezni, hogy a déli órákat hűvösben tölthessük!

\section{Szmogriadó}

A szmogriadót a települési önkormányzat rendeli el az Országos Légszennyezettségi Mérőhálózat mérései alapján. Az időjárási veszélyjelzésekkel szemben a szmogriadó nem elörejelzés. Akkor rendelik el, ha a szmoghelyzet már kialakult, és a magas légszennyezettség fennmaradásáig van érvényben. Csak azokon a településeken rendelik el, amelyek rendelkeznek légszennyezettség-mérő állomással. Tájékoztatási és riasztási fokozata van; előbbi csak a lakosság tájékoztatására szolgál, utóbbihoz általában kötelező érvényű korlátozások is tartoznak.

\section{Teendök}

Lakásunk szellőztetését és a szabadtéri tevékenységeket a tisztább (nappali) órákban végezzük, éjszakára pedig húzódjunk zárt ajtók és ablakok mögé! A halasztható sporteseményeket és fizikai munkát szervezzük későbbre! Egészséges táplálkozással, a káros szenvedélyek mellőzésével enyhítsük a légszennyezés egészségi hatásait! Fűtés, közlekedés, kertészkedés terén tanúsított felelős magatartással kerüljük el a szmog súlyosbodását!

\section{ÖSSZEGZÉS}

A veszélyes időjárási jelenségekkel kapcsolatban elmondható, hogy a legnagyobb kárt mindig a meglepetés okozza. Ma már ki-ki a zsebében hordhatja a korszerü müholdak, 
radarok és szuperszámítógépek segítségével kiadott meteorológiai riasztásokat. Megengedhetetlen, hogy modern világunk adottságai mellett a veszélyes időjárás bárkit meglepetésként érjen. Különösen évszakváltásoknál fontos a tájékozódás: ősszel az első ködök és fagyok, tavasszal az első viharok és a napsugárzásnak köszönhető leégések gyakran felkészületlenül érik azokat, akik nem követik az időjárás-előrejelzést. Nem szabad alábecsülni az időjárás tér- és időbeli változékonyságát. Sokszor csak percek vagy kilométerek választják el a napsütést a felhőszakadástól, az esőt a havazástól, vagy a nedves utat a tükörjégtől. Gondoljunk erre akkor is, amikor a meteorológiai veszélyjelzések beválását értékeljük! Valóban elmaradt a veszélyes időjárási esemény, vagy csak szerencsésen elkerült minket? Természetesen az előrejelzések nem hibátlanok; segítségükkel mégis komoly anyagi károktól és életveszélyes helyzetektől óvhatjuk meg magunkat és szeretteinket.

\section{IRODALOM}

Apatóczky István (2004): A Széltörési-erdő születése. - Erdészeti Lapok 139. 9. pp. 273-275.

Bartholy Judit - Mészáros Róbert - Geresdi István - Matyasovszky István - Pongrácz Rita - Weidinger Tamás (2013): Meteorológiai alapismeretek. - Eötvös Loránd Tudományegyetem, Budapest. 259 p. https://ttk.elte.hu/dstore/document/885/book.pdf

Czigány Szabolcs - Pirkhoffer Ervin (2018): Villámárvíz-veszélyeztetettség. - In: Kocsis Károly (föszerk.): Magyarország Nemzeti Atlasza. Természeti környezet. MTA Csillagászati és Földtudományi Kutatóközpont, Budapest. p. 165. https://www.nemzetiatlasz.hu/MNA/National-Atlas-of-Hungary_ Vol2_Ch13.pdf

Hadvári Marianna - Szegedi Csaba - Csirmaz Kálmán - Németh Péter (2018): Az Országos Meteorológiai Szolgálat időjárási radarhálózatának mérései. - Országos Meteorológiai Szolgálat, Budapest. 23 p. https://www.met.hu/downloads.php?fn=/ismertetok/radar_ismerteto.pdf

MÉszÁros Róbert (2013): Időjárási radarmérések. - In: Meteorológiai Müszerek és Mérőrendszerek. Eötvös Loránd Tudományegyetem, Budapest. pp. 156-163. https://ttk.elte.hu/dstore/document/886/ book.pdf

SÁNdor VALÉRIA - WANTuCh Ferenc (2005): Zivatar. - In: Repülésmeteorológia. Országos Meteorológiai Szolgálat, Budapest. pp. 166-175.

A regionális diszpécserszolgálatok elérhetősége. - Menhely Alapítvány. http://www.menhely.hu/index. php/161-menhely-honlap-ftartalom/diszpecser [utolsó megtekintés 2021. 10. 25.]

Az Országos Meteorológiai Szolgálat veszélyjelző rendszere. - OMSZ, Budapest. https://www.met.hu/ idojaras/veszelyjelzes/omsz_veszelyjelzo_rendszere/

Közlekedési baleseti statisztikai évkönyv, 2015. - Központi Statisztikai Hivatal, Budapest. p. 18.

Magyar Biztosítók Szövetsége (2020): Öt éve nem volt ilyen drága viharszezonja a biztosítóknak. - https:// mabisz.hu/ot-eve-nem-volt-ilyen-draga-viharszezonja-a-biztositoknak/ [utolsó megtekintés 2021. 10. 25.] 
Mezőgazdasági biztosítások 2020. év. - AKI Agrárközgazdasági Intézet, Budapest. 2021. Statisztikai Jelentések 5. 1.

Villámcsapásokról. - BM Országos Katasztrófavédelmi Főigazgatóság, Budapest. 2013. https://www. katasztrofavedelem.hu/197/kozlemenyek/7051/villamcsapasokrol 